\title{
Selekcja jako instrument kształtowania wizerunku pracodawcy
}

\begin{abstract}
ANNA DOLOT
Katedra Zarządzania Zasobami Pracy, Uniwersytet Ekonomiczny w Krakowie

Celem artykułu jest prezentacja wybranych elementów, które w procesie selekcji pracowników mają określony wpływ na kształtowanie wizerunku firmy, jako pracodawcy. W pierwszej kolejności zdefiniowano pojęcie selekcji oraz jej kluczowych metod. Szczególną uwage skupiono na wywiadzie oraz Assessment Center. Następnie scharakteryzowano pojęcie wizerunku oraz wizerunku pracodawcy. Najistotniejszą częścią artykułu są wyniki badań empirycznych. Badania prowadzone były wśród pracowników dużych przedsiębiorstw na terenie miasta Krakowa i dotyczyły wybranych elementów procesu selekcji i ich wpływu na kształtowanie wizerunku firmy, jako pracodawcy.
\end{abstract}

Słowa kluczowe: kształtowanie wizerunku, pracodawca, selekcja, wywiad selekcyjny (rozmowa kwalifikacyjna), Assessment Center.

\section{Wstęp}

Pojęcie wizerunku pracodawcy wydaje się coraz bardziej znane i powszechne. Niewątpliwie istnieje wiele czynników, które mają wpływ na tworzenie i kształtowanie wizerunku pracodawcy. Choć coraz więcej organizacji zabiega o pozytywne kształtowanie swojego wizerunku, wydawać się może, że obszar związany z procesem doboru pracowników jest niedoceniany. Z jednej strony współcześnie, w dobie niepewnej sytuacji gospodarczo-ekonomicznej dominuje rynek pracodawcy, z drugiej kandydat do pracy nie zawsze bywa utożsamiany z potencjalnym klientem, dostawcą, partnerem biznesowym. Dodatkowo niedoceniany wydaje się obszar emocjonalnego zaangażowania kandydata w procesie poszukiwania pracy i jego ocena firmy, nie tylko jako potencjalnego pracodawcy, ale i dostawcy określonych dóbr czy usług. Celem niniejszego artykułu jest próba odpowiedzi na pytanie: w jaki sposób poszczególne elementy procesu selekcji (z wyraźnym oddzieleniem 
jej od procesu rekrutacji) są postrzegane przez pracowników w kontekście kształtowania wizerunku pracodawcy.

W artykule odwołano się zarówno do analizy literatury przedmiotu, jak i samodzielnie przeprowadzonych badań empirycznych autorki.

\section{Charakterystyka procesu selekcji}

Zarówno proces rekrutacji, jak i selekcji według niektórych autorów stanowi znaczącą część procesu, jakim jest dobór pracowników. Część specjalistów uważa, że dobór pracowników w wąskim ujęciu to właśnie: rekrutacja, selekcja oraz wprowadzenie do pracy (Kawka, Listwan, 2010). W szerokim ujęciu pojęcie doboru pracowników składa się z następujących etapów:

- przygotowania doboru (analiza pracy, opracowanie profilu wymagań);

- dobór właściwy (działania rekrutacyjne, proces selekcji, wprowadzenie do pracy);

- kontrola procesu doboru (ocena po okresie próbnym, weryfikacja rzeczywistych wyników) (Kawka, Listwan, 2010).

Można zatem powiedzieć, że dobór pracowników w wąskim ujęciu to dobór właściwy w ujęciu szerokim. W niniejszym artykule proces doboru pracowników rozumiany jest w ujęciu wąskim.

Choć w potocznym języku często mówi się o rekrutacji (jako całościowym procesie doboru pracowników), czy o prowadzeniu rozmowy rekrutacyjnej, zarówno w literaturze przedmiotu, jak i praktyce biznesowej pojawia się pojęcie selekcji, które przez wielu specjalistów odróżniane jest od procesu rekrutacji.

Jeden ze specjalistów w obszarze zarządzania zasobami ludzkimi definiuje pojęcie selekcji w następujący sposób: „selekcja kandydatów jest procesem oceny przydatności kandydatów i wyborem jednego z nich, najbardziej odpowiedniego z punktu widzenia wymagań stanowiska pracy i oczekiwań pracodawcy" (Ludwiczyński, 2006). W praktyce biznesowej może zdarzyć się sytuacja, w której wybierany jest więcej niż jeden kandydat. Warto zacytować również inną definicję, oddającą charakter terminu „selekcja” oraz jej powiązanie z nadmienioną już rekrutacją. Jak podaje jeden z ekspertów jest to: „zespół działań mający na celu wybranie przy pomocy określonych metod, technik i narzędzi odpowiedniego pracownika spośród rekrutowanej grupy kandydatów na określone stanowisko według przyjętych kryteriów w profilu kwalifikacyjnym danego stanowiska" (Listwan, 2005). Podsumowując zatem powyższe definicje proces selekcji będzie rozumiany jako proces następujący po rekrutacji (która kończy się w momencie zebrania odpowiedniej ilości dokumentów aplikacyjnych), a jego celem jest wybór 
(przy pomocy zróżnicowanych metod i narzędzi), właściwego/właściwych kandydatów, którzy zostaną zatrudnieni na danym stanowisku pracy.

W ramach procesu selekcji można wyróżnić następujące metody (Marek, 2008):

- analiza dokumentów aplikacyjnych (listy motywacyjne, CV, ankiety personalne, referencje);

- $\quad$ testy selekcyjne (testy psychologiczne, wiedzy, psychomotoryczne, medyczne);

- $\quad$ wywiady (rozmowy kwalifikacyjne);

- Assessment Center (centrum oceny, ośrodek oceny).

Należy podkreślić, że są to najczęściej występujące i najbardziej znane metody selekcji (na te położono największy nacisk w czasie prowadzonych badań), jednakże w literaturze przedmiotu można spotkać się z kilkoma innymi metodami. Wyróżnia się np. wywiad telefoniczny jako metodę, którą powinna poprzedzać, a czasem nawet może zastąpić rozmowę kwalifikacyjną (Suchar, 2005). Spotkać się można także ze zbieraniem referencji (pisemnych, telefonicznych), które jednak należy traktować z dużą ostrożnością (Armstrong, 2005). Istnieje też grafologia definiowana jako badanie społecznych cech człowieka poprzez styl jego pisma, która bywa wykorzystywana w procesie selekcji, jednakże uznaje się ją raczej za metodę niekonwencjonalną.

W kontekście selekcji oraz jej wpływu na kształtowanie wizerunku pracodawcy (o czym szerzej będzie mowa w dalszej części artykułu) ważne do wyjaśnienia wydają się szczególnie dwie metody, a mianowicie „wywiad” oraz „Assessment Center".

Wywiad to rozmowa kwalifikacyjna przeprowadzana z kandydatem do pracy przez osobę lub osoby dokonujące selekcji (Ludwiczyński, 2006). Celem wywiadu jest uzupełnienie i zweryfikowanie informacji, które kandydat zawarł w dokumentach aplikacyjnych, zbadanie motywacji kandydata do podjęcia oferowanej pracy, jak również jego oczekiwań wobec potencjalnego pracodawcy. Wywiad powinien również służyć zaprezentowaniu firmy oraz stanowiska, o które kandydat się ubiega. To jedna z najlepszych okazji do kształtowania wizerunku firmy, jako pracodawcy w procesie selekcji. Jak pisze jedna ze specjalistek wywiad to najczęściej pierwsze spotkanie kandydata z kadrą kierowniczą firmy, a opinia o jej fachowości, wpłynie na sposób postrzegania przez niego całego przedsiębiorstwa (por. Jamka, 2001).

O wiele bardziej złożoną i czasochłonną zarówno w przygotowaniu, jak i prowadzeniu metodą jest Assessment Center (AC). Jest to metoda wykorzystywana do selekcji kandydatów na określone stanowisko poprzez ich udział w szerokiej gamie ćwiczeń oddających zadania oraz trudne sytuacje na tym stanowisku pracy (specyfikę i charakter pracy). Zachowania kandydatów są obserwowane 
i oceniane (przez tzw. asesorów). Kandydat lub kandydaci otrzymujący najlepsze oceny w poszczególnych ćwiczeniach i zadaniach zostają wyselekcjonowani, czyli zatrudnieni (Dolot, 2010). Choć w związku z przygotowaniem i prowadzeniem AC związane są stosunkowo duże nakłady czasowe i finansowe, to jednak metoda ta często uważana jest za najskuteczniejszą i najbardziej kompleksową spośród wszystkich metod selekcji kandydatów. Dodatkowo uważana jest za najlepszą metodę do oceny kompetencji (Wood, Payne, 2006), co w kontekście oceny kompetencji zewnętrznych kandydatów, których obserwacja w realnym środowisku pracy jest trudna lub nierealna, wydaje się wyjątkowo cenne.

\section{Istota wizerunku pracodawcy}

W pierwszej kolejności warto dokonać analizy definicji określenia „wizerunek”, w oderwaniu od kontekstu pracodawcy. Słowo „wizerunek” pochodzi z języka łacińskiego (imago) i oznacza wzór, pierwowzór, odbicie, obraz. To wypracowane (często przez specjalistów w tym zakresie) publiczne oblicze osoby lub organizacji, które przedstawia ją w korzystnym świetle i służy zdobywaniu społecznej akceptacji dla jej działalności, a tym samym pozyskiwaniu coraz większych rzesz sympatyków, klientów (Dunaj, 2006). Oznacza to zatem, iż wszelkie działania kierowane są do potencjalnych klientów, którzy (poprzez zakup dóbr czy usług) decydują o kondycji danej organizacji na rynku. W tym rozumieniu wizerunek jest obszarem zainteresowań głównie specjalistów w zakresie marketingu. Należy jednak podkreślić, że istotnym klientem danej organizacji oraz jej wizytówką jest jej obecny oraz potencjalny pracownik. Stąd też pojawiło się pojęcie wizerunku firmy, jako pracodawcy, czyli wizerunku pracodawcy. Jak pisze jeden ze specjalistów w obszarze kształtowania wizerunku pracownicy danej organizacji mają szczególne znaczenie w przypadku firm wytwarzających usługi rynkowe, ale i organizacji non-profit. Podkreśla on, iż to właśnie pracownik (a właściwie jego sposób zachowania) może być tym czynnikiem, który wyróżnia daną organizację. Wyróżnienie się personelem wymaga od firmy starannego doboru osób mających kontakt z klientami, a następnie dobrego ich wyszkolenia (Altkorn, 2004). Już w tej definicji proces rekrutacji i selekcji wydaje się mieć istotny wpływ na kształtowanie wizerunku firmy jako pracodawcy.

Zanim jednak będzie miało miejsce przejście do wyjaśnienia terminu „wizerunek pracodawcy" należy zwrócić uwagę na jeszcze jeden, bardzo istotny aspekt. W jednej z definicji wizerunku organizacji podkreśla się, iż jest to całokształt wyobrażeń, oczekiwań, przekonań oraz wiedzy z nią związanej. Wizerunek stanowi zespół zarówno atrybutów racjonalnych, jak i emocjonalnych odnoszących 
się do danego przedsiębiorstwa. Powstają one na skutek świadomych i nieświadomych działań podmiotu gospodarczego. Jest to zatem obraz danej organizacji w świadomości społecznej, czyli to, co poszczególne jednostki o niej myślą, jak ją oceniają oraz jakie postawy wobec niej przyjmują (Urbaniak, 2003). Pojawia się tu zatem element o zabarwieniu emocjonalnym, co może pociągać za sobą fakt, że wizerunek ma charakter subiektywny, związany z emocjami poszczególnych osób (klientów, pracowników, partnerów biznesowych). I tak jak ludzie odmiennie, emocjonalnie reagują na różne działania, czynniki, sytuacje, zachowania, ogólnie mówiąc bodźce, tak różny (stały jedynie w danej chwili) może być wizerunek organizacji dla danego człowieka. Zatem emocjonalny czynnik w odniesieniu do wizerunku ma istotne znaczenie i może odgrywać znaczącą rolę w kontekście procesu rekrutacji i selekcji.

W literaturze przedmiotu można znaleźć wiele definicji wizerunku pracodawcy. Jedna z obszerniejszych wskazuje, iż jest on jej obrazem (odbiciem) ukształtowanym w świadomości aktualnych i potencjalnych pracowników na bazie ich osobistych doświadczeń (w przypadku osób zatrudnionych w firmie) lub też informacji docierających od potencjalnych członków organizacji, których źródłem są osoby tworzące daną organizację oraz wszelkiego typu nośniki masowego przekazu (Baruk, 2006).

Na wizerunek pracodawcy może wpływać wiele czynników. Mogą one wynikać zarówno z jej wnętrza, jak również otoczenia, w którym działa. Wskazać można zatem następujące, przykładowe, determinanty wizerunku pracodawcy:

- $\quad$ zewnętrzne (branża, przepisy prawne, sytuacja na rynku pracy);

- wewnętrzne (ogólny wizerunek organizacji, kultura organizacyjna, styl zarządzania, strategia organizacji, struktura organizacyjna, jakość zarządzania zasobami ludzkimi i jakość tych zasobów) (Bukowska, 2009).

Należy podkreślić, że specyfika kształtowania wizerunku pracodawcy w kontekście procesu selekcji oraz wcześniej podkreślanej komponenty emocjonalnej jest szczególna - jest to bowiem proces, który najczęściej w znaczącym stopniu angażuje emocjonalnie kandydatów. Wynika to z faktu, iż mogą oni znajdować się w różnej sytuacji życiowej i osobistej (np. trudnej z punktu widzenia ekonomicznego), są poddawani ocenie, mają przed sobą pespektywę istotnej zmiany życiowej (związanej nierzadko ze zmianą sposobu życia, przyzwyczajeń, być może miejsca zamieszkania), uczenia się czegoś nowego. Należy jednocześnie zaznaczyć, iż specyfika procesu selekcji (szczególnie w trudnej sytuacji gospodarczej) stawia pracodawcę niejako w lepszej sytuacji - oferującego stanowisko pracy, na które najczęściej aplikuje wielu kandydatów (choć w coraz powszechniejszej opinii niekoniecznie tych właściwych i wartościowych). Stąd osoby prowadzące proces selekcji, posiadające niską świadomość roli każdego działania, w którym 
ma miejsce kontakt z człowiekiem (pracownikiem, kandydatem) mogą utrudnić budowanie pozytywnego wizerunku organizacji (tak na rynku pracy, jak i na rynku dóbr i usług).

W tym miejscu należy podkreślić, że przy wykorzystaniu takich metod selekcji jak wywiad, czy AC potencjalny pracownik ma bezpośredni kontakt z daną organizacją. Poprzez kontakt z pracownikami danej firmy, poznaje sposób komunikacji, podejścia do pracowników, w pewnym stopniu kulturę organizacyjną, formalne i nieformalne zasady panujące $\mathrm{w}$ danej firmie. W przypadku AC kandydat stosunkowo dużo czasu spędza w środowisku stworzonym przez potencjalnego pracodawcę (AC może odbywać się w siedzibie danej firmy, najczęściej realizowane jest przy znacznym zaangażowaniu jej poszczególnych pracowników), co daje mu jeszcze lepszą okazję do obserwacji i tworzenia obrazu firmy w swoim odczuciu. Kandydat będzie miał zatem czas i możliwości, aby wyrobić sobie określone zdanie na temat danej firmy. Jak już wcześniej podkreślono, niezwykle istotny jest tu aspekt emocjonalny. Fakt, że kandydat znajduje się w dużym stresie powoduje, że na każdą sytuację może reagować bardziej emocjonalnie, niż w normalnych warunkach. Szczególnie silnie będzie odbierał wszelkie negatywne zachowania, gesty, słowa. Celem prowadzenia procesu selekcji powinno być takie nim zarządzanie, aby w sytuacji odmowy w pracowniku wzbudzić poczucie utraconej możliwości pracy w pozytywnie ocenianym środowisku, a nie złości, zdenerwowania, gniewu, czy ulgi lub obojętności.

Pozostaje pytanie, na jakie elementy z obszaru selekcji zwracają uwagę pracownicy - kluczowi uczestnicy rynku pracy?

\section{Wyniki badań empirycznych}

Badania empiryczne zostały przeprowadzone w roku 2013, na terenie Krakowa. Wzięło w nich udział 122 pracowników z dużych firmy (zarówno polskich, jak i międzynarodowych).

W pierwszej kolejności kwestionariusze skierowane zostały do poszczególnych firm (np. do działów, czy pracowników odpowiedzialnych za politykę zarządzania zasobami ludzkimi) w celu zbadania, jakie metody selekcji są przez nie wykorzystywane. Strukturę uzyskanych odpowiedzi przedstawia wykres 1.

Jak wynika z wykresu zdecydowanie najczęściej stosowanymi metodami są: analiza CV oraz rozmowa kwalifikacyjna. Metody, które nie są w ogóle wykorzystywane to: grafologia i analiza ujednoliconych formularzy on-line (co stanowi pewne zaskoczenie, gdyż autorka kilkukrotnie, szczególnie w korporacjach międzynarodowych spotykała się z tą metodą selekcji). 
Wykres 1. Wykorzystanie metod selekcji w badanych firmach

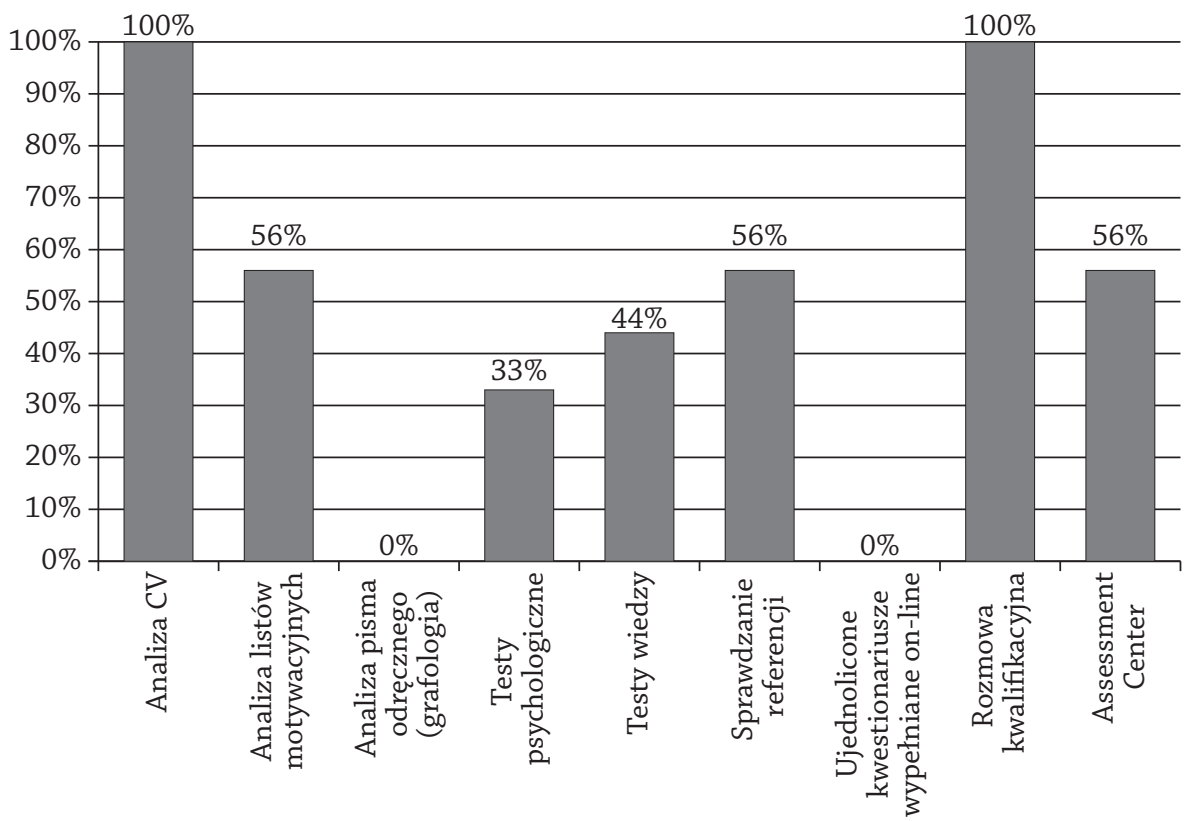

Źródło: opracowanie własne na podstawie samodzielnych badań empirycznych.

Pytanie o najczęściej spotykane metody selekcji zostało również postawione badanym respondentom (jednakże w mniejszym zakresie, gdyż z perspektywy pracownika, a nie jak we wcześniejszym pytaniu pracodawcy dokonującego selekcji). Mieli oni wybrać dwie najczęściej spotykane metody. Strukturę ich odpowiedzi przedstawia wykres 2.

W świetle przeprowadzonych badań należy podkreślić, że rozmowa kwalifikacyjna wydaje się mieć bardzo istotne znaczenie jako czynnik kształtowania wizerunku pracodawcy. Dowodem jest fakt, że aż $75 \%$ badanych respondentów zdecydowanie zgadza się ze stwierdzeniem, iż sposób przeprowadzenia rozmowy kwalifikacyjnej wpływa na kształtowanie wizerunku firmy. Strukturę odpowiedzi przedstawia wykres 3 .

Co ciekawe odpowiedzi „nie zgadzam się” udzielili mężczyźni oraz osoby zajmujące stanowiska specjalistyczne (ani jedna osoba na stanowisku kierowniczym nie wskazała takiej odpowiedzi). Istotne jest zatem, aby rozmowa była przeprowadzona w sposób partnerski, grzeczny, uporządkowany, przez przygotowane do tego osoby, bez zadawania pytań, które prawnie są niedopuszczalne (ze szczególnym uwzględnieniem artykułu 18 3a $\S 1$. Kodeksu Pracy). 
Wykres 2. Najczęściej spotykane metody selekcji w opinii badanych respondentów

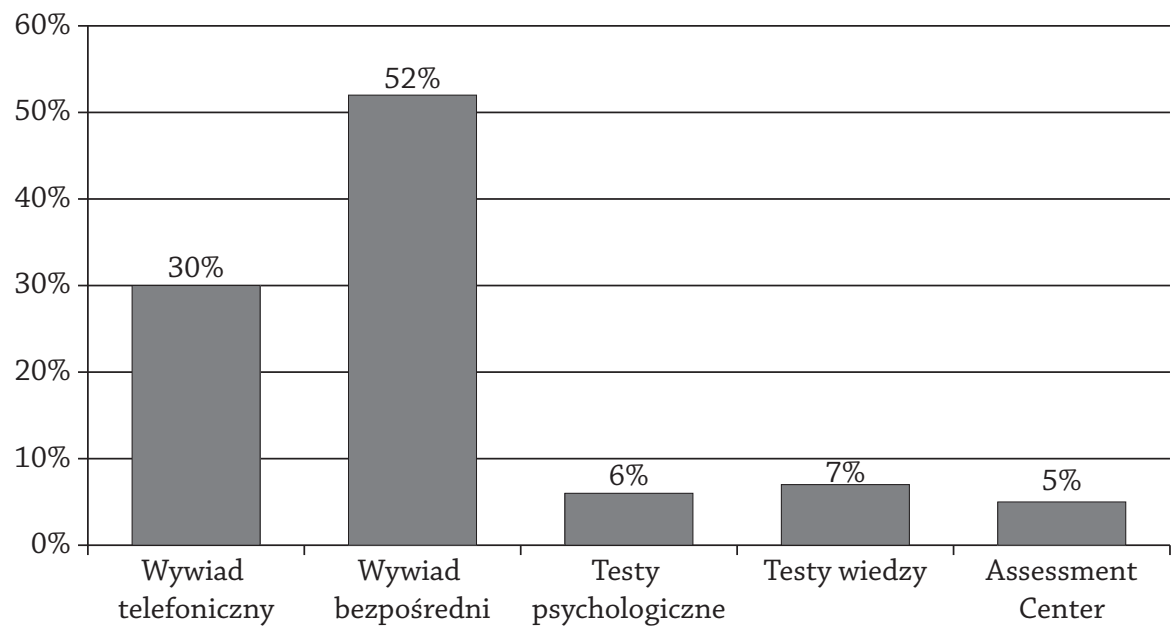

Źródło: opracowanie własne na podstawie samodzielnych badań empirycznych.

Wykres 3. Struktura odpowiedzi na pytanie, czy sposób przeprowadzenia rozmowy kwalifikacyjnej wpływa na kształtowanie wizerunku firmy

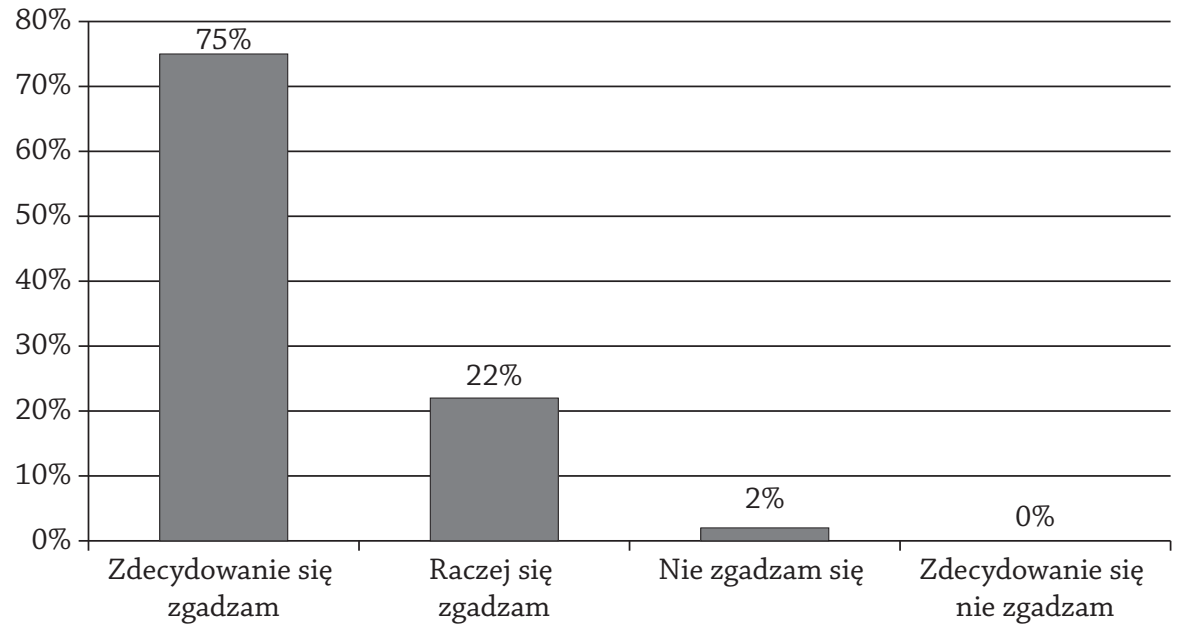

Źródło: opracowanie własne na podstawie samodzielnych badań empirycznych.

W świetle przeprowadzonych badań wydaje się, że zróżnicowanie stosowania metod selekcji (więcej niż jednej) nie ma większego wpływu na to czy dana firma jest postrzegana lepiej czy gorzej. Strukturę odpowiedzi przedstawia wykres 4.

Należy jednak podkreślić, że ma to z pewnością wpływ na właściwe podejmowanie decyzji w procesie selekcji. 
Wykres 4. Struktura odpowiedzi na stwierdzenie, że zróżnicowane stosowanych metod selekcji (więcej niż jedna) ma wpływ na lepsze postrzeganie firmy, niż tych, które stosują tylko jedną metodę selekcji

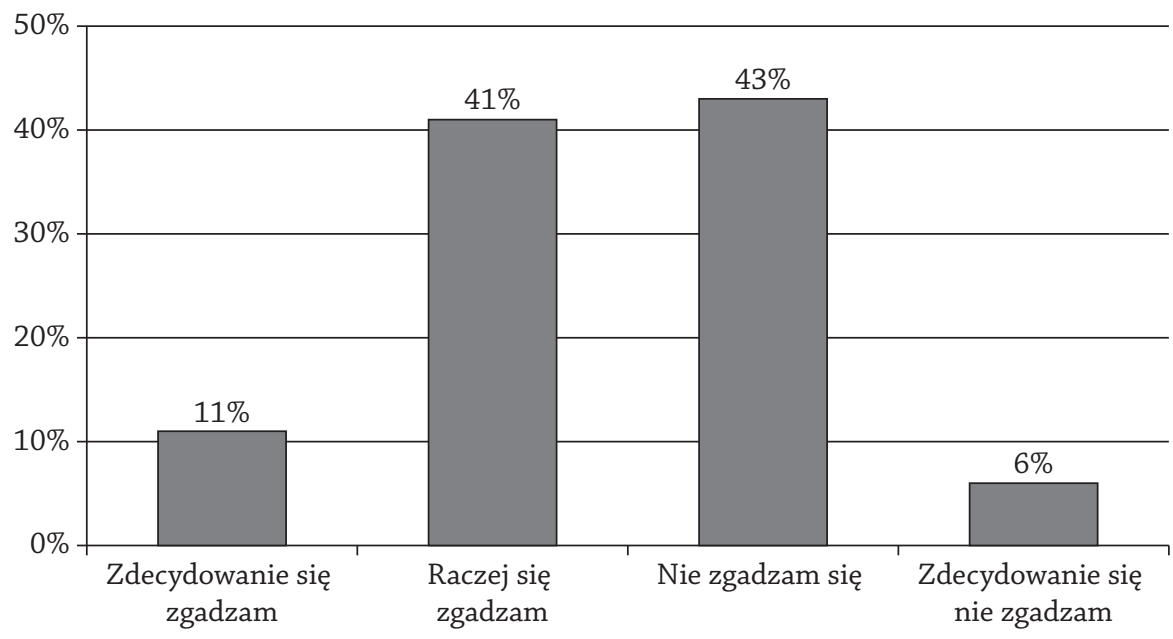

Źródło: opracowanie własne na podstawie samodzielnych badań empirycznych.

Ciekawa natomiast wydaje się struktura odpowiedzi na stwierdzenie, iż firmy, które stosują Assessment Center jako metodę selekcji postrzegane są lepiej niż te, które jej nie stosują (wykres 5).

Wykres 5. Struktura odpowiedzi na stwierdzenie, iż firmy, które stosują AC jako metodę selekcji postrzegane są lepiej niż te, które jej nie stosują

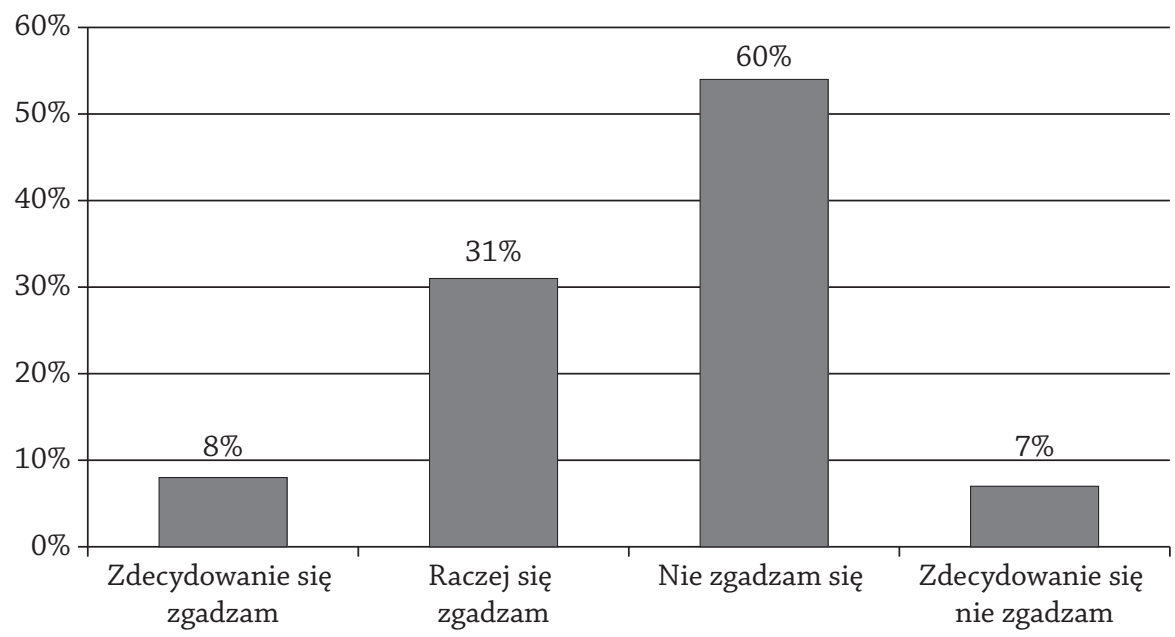

Źródło: opracowanie własne na podstawie samodzielnych badań empirycznych. 
Okazuje się, że tak zaawansowana i złożona metoda wcale nie wpływa na pozytywne kształtowanie wizerunku przedsiębiorstwa jako pracodawcy. Być może wynika to $z$ faktu, że jest to metoda stresująca, angażująca czasowo, a niewłaściwie przeprowadzona pozostawia raczej przykre niż pozytywne odczucia.

W potocznych opiniach często można spotkać się ze stwierdzeniem, że pracodawcy nie udzielają kandydatom zaangażowanym w proces selekcji żadnej informacji zwrotnej po zakończeniu tegoż procesu. W badaniach niestety potwierdziły się te opinie. Aż $78 \%$ respondentów potwierdziło, że zdarzyło im się wziąć udział w procesie rekrutacji i selekcji i nie otrzymać żadnej informacji zwrotnej od danej firmy. Jest to raczej nieprzemyślane działanie ze strony firm, ponieważ jak wynika z wykresu 6 aż 96\% pracowników takiego pracodawcę ocenia zdecydowanie źle lub źle.

Wykres 6. Struktura odpowiedzi na pytanie, jak respondenci oceniają pracodawców, którzy nie udzielają informacji zwrotnej po zakończonym procesie rekrutacji i selekcji

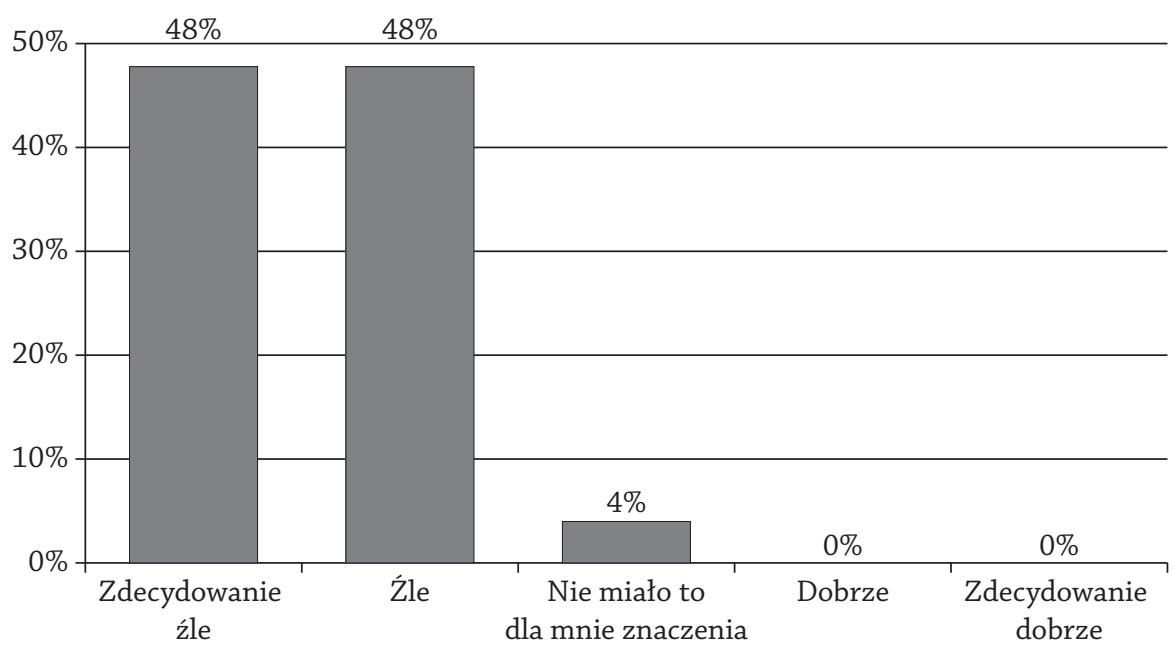

Źródło: opracowanie własne na podstawie samodzielnych badań empirycznych.

Ma to zatem znaczący wpływ na kształtowanie wizerunku danej firmy, jako pracodawcy szczególnie, że pozostawia daną osobę (kandydata) w sytuacji niepewności. Trudno szukać wytłumaczenia takiego działania brakiem czasu, najczęściej bowiem informacja zwrotna kierowana jest do osób, które doszły do etapu wywiadu, czy AC, a to z reguły nie jest aż tak liczna grupa kandydatów. Trudno też to tłumaczyć ograniczeniami finansowymi, gdyż jak wynika z wykresu $7 \mathrm{dla}$ 
niemal $40 \%$ procent wystarczającą formą jest odpowiedź drogą mailową (która związana jest raczej z ograniczonymi nakładami finansowymi).

Wykres 7. Struktura odpowiedzi na pytanie: Jaki sposób udzielenia informacji zwrotnej po procesie rekrutacji i selekcji uważasz za najodpowiedniejszy

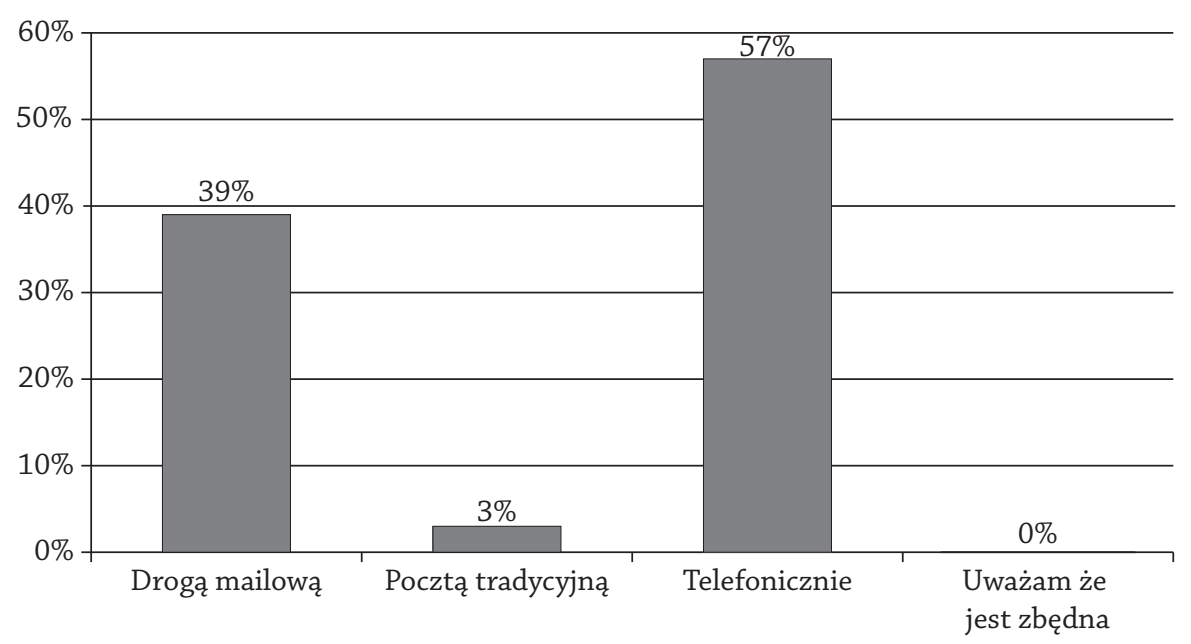

Źródło: opracowanie własne na podstawie samodzielnych badań empirycznych.

Ponieważ sam pracownik poświęca na ogół wiele czasu i zaangażowania w proces rekrutacji i selekcji, brak jakiejkolwiek informacji po zakończeniu tych procesów wydaje się być nietaktem i raczej nieprzemyślanym działaniem.

Zbierając powyższe, wybrane elementy procesu selekcji, z którymi kandydaci mają bezpośrednią styczność (np. wykorzystywanie zróżnicowanych metod selekcji, sposób przeprowadzenia rozmowy kwalifikacyjnej, udzielanie informacji zwrotnej po procesie selekcji) należy mieć na uwadze, że proces selekcji może wpłynąć na motywację kandydata do pracy. Może go zatem zachęcić i zmotywować do podjęcia pracy lub zniechęcić i wzbudzić negatywne odczucia. W tej drugiej sytuacji, jeżeli pracownik zostanie zatrudniony jego pierwsze wrażenie po kontakcie z firmą będzie już negatywne, co może rzutować na dalszą współpracę. Jeżeli zaś nie zostanie zatrudniony jego negatywne emocje mogą skutkować brakiem dokonywania zakupów czy korzystania z usług danej firmy i/lub szerzeniem niepochlebnych informacji na rynku pracy. Może zdarzyć się również i tak, że wartościowy pracownik, którego firma będzie chciała zatrudnić sam zrezygnuje z podjęcia pracy na podstawie negatywnych odczuć po procesie selekcji. W każdym zatem przypadku konsekwencje są dla firmy niekorzystne. 


\section{Podsumowanie}

Proces selekcji w przypadku większości jej uczestników jest dla nich angażujący zarówno z uwagi na poświęcony czas, jak i emocje. Poszukiwanie i zmiana pracy są związane ze stresem i niepewnością, dlatego niektóre sytuacje mogą być odbierane w sposób bardziej wyrazisty. Oznacza to, że proces selekcji, w którym kandydat ma kontakt z firmą oraz jej pracownikami jest doskonałą okazją do wzbudzenia pozytywnych odczuć, a w konsekwencji kształtowania pozytywnego wizerunku. Pomimo, iż obiegowo mówi się, że rynek pracy jest obecnie rynkiem pracodawcy, niełatwo jest znaleźć dobrego, cennego, właściwego pracownika. $\mathrm{Na}$ podstawie przeprowadzonych badań empirycznych można wnioskować, że nieprofesjonalne traktowanie kandydatów podczas procesu selekcji (ze szczególnym uwzględnieniem takich czynników jak: niewłaściwy sposób prowadzenia rozmowy kwalifikacyjnej, brak informacji zwrotnej po zakończeniu procesu selekcji) negatywnie wpływa na kształtowanie wizerunku firmy, jako pracodawcy. W konsekwencji może to skutkować zarówno zniechęceniem do podjęcia pracy przez tych najlepszych kandydatów, jak i rozpowszechnianiem się na rynku niepochlebnych informacji o danej organizacji (zarówno na rynku pracy, jak i dóbr i usług).

\section{Bibliografia}

Altkorn, J. (2004), Wizerunek firmy, Wyższa Szkoła Biznesu w Dąbrowie Górniczej, Dąbrowa Górnicza.

Armstrong, M. (2005), Zarzq̨dzanie zasobami ludzkimi, Oficyna Ekonomiczna, Kraków.

Baruk, A. I. (2006), Marketing personalny jako instrument kreowania wizerunku firmy, Difin, Warszawa.

Bukowska, U. (2009), Rola kultury organizacyjnej w kształtowaniu wizerunku pracodawcy, w: M. Juchnowicz (red.), Kulturowe uwarunkowania zarządzania kapitałem ludzkim, Wolters Kluwer Polska, Kraków.

Dolot, A. (2010), Determinanty kształtowania i udzielania informacji zwrotnej w procesie Development Center, w: T. Wawak (red.), Komunikacja i jakość w zarządzaniu, Wydawnictwo Uniwersytetu Jagiellońskiego, Kraków.

Dunaj, B. (1996) (red.), Stownik wspótczesnego języka polskiego, Wilga, Warszawa. Jamka, B. (2001), Dobór zewnętrzny i wewnętrzny pracowników, Difin, Warszawa. Kawka T., Listwan T. (2010), Dobór pracowników, w: T. Listwan (red.), Zarzq̨dzanie kadrami, Wydawnictwo C. H. Beck, Warszawa.

Listwan, T. (2005) (red.), Słownik zarzadzania kadrami, C. H. Beck, Warszawa. 
Ludwiczyński, A. (2006), Alokacja zasobów ludzkich organizacji, w: H. Król, A. Ludwiczyński (red.), Zarzq̨dzanie zasobami ludzkimi, Wydawnictwo Naukowe PWN SA, Warszawa.

Marek, J. (2008), Koncepcje i metody doboru menedżerów, w: A. Sajkiewicz (red.), Kompetencje menedżerów w organizacji uczącej się, Difin, Warszawa.

Pocztowski, A. (2003), Zarządzanie zasobami ludzkimi, Polskie Wydawnictwo Ekonomiczne, Warszawa.

Suchar, M. (2005), Rekrutacja i selekcja personelu, C. H. Beck, Warszawa.

Urbaniak, M. (2003), Wizerunek dostawcy na rynku dóbr i usług, Wydawnictwo Uniwersytetu Łódzkiego, Łódź.

Wood, R., Payne, T. (2006), Metody rekrutacji i selekcji pracowników oparte na kompetencjach, Oficyna Ekonomiczna, Kraków.

\section{Summary}

\section{Personnel Selection as Instrument of Employer Branding}

The aim of the article is to present selected elements which can in different way influence employer branding in the personnel selection process. In the first place the term of personnel selection process and its methods were defined. Special attention was paid to job interview and Assessment Center. Next, the term of employer branding was explained. The most important part of the article discussed the results of empirical research that was conducted in large companies based in Cracow. The aim of the research was to show which selection methods were used and what the influence of different personnel selection elements on employer branding is.

Keywords: corporate image, employer, personnel selection, job interview, Assessment Center.

\section{Резюме}

\section{Процесс отбора как эмемент формированя имиджа работодатемя}

Цель статьи - презентация выбранных элементов, которые в процессе отбора персонала оказывают определенное влияние на формирование имиджа фирмы как 
работодателя. В первую очередь дефинированы понятия отбора, а также его ключевых методов. Особое внимание сосредоточено на интервью, а также Assessment Center. Затем охарактеризованы понятия имиджа и имиджа работодателя. Самой существенной частью статьи являются результаты эмпирических исследований. Исследования проводились среди сотрудников больших предприятий на территории города Кракова и касались выбранных элементов процесса отбора и их влияния на формирование имиджа фирмы как работодателя.

Ключевые слова: формирование имиджа, работодатель, отбор, отборочное интервью (собеседование), Assessment Center.

\section{Anna Dolot}

Pracownik naukowo-dydaktyczny w Katedrze Zarządzania Zasobami Pracy na Uniwersytecie Ekonomicznym w Krakowie. Naukowe obszary jej zainteresowań stanowią zagadnienia związane z rozwojem pracowników, ich pozyskiwaniem i ocenianiem (szczególnie przy wykorzystaniu takich metod jak Assessment i Development Center). Otworzyła przewód doktorski i prowadzi badania w obszarze wpływu coachingu na rozwój kompetencji pracowników. 